JKKP : Jurnal Kesejahteraan Keluarga dan Pendidikan

http://doi.org/10.21009/JKKP

DOI: doi.org/10.21009/JKKP.062.06

E-ISSN : 2597-4521

\title{
PROGRAM PENYULUHAN PERAWATAN KEBERSIHAN DIRI (PERSONALHYGIENE) BERBASIS LIFE SKILL UNTUK ANAK PRASEKOLAH DI PANTI SOSIAL ASUHAN ANAK
}

\author{
Neni Rohaeni ${ }^{1, a)}$, Afifah Azzahra ${ }^{2, b)}$, Yoyoh Jubaedah ${ }^{3, c)}$ \\ a)nenirohaeni@upi.edu, b)alexafifah.azzahra@gmail.com, c)yoyohjubaedah@upi.edu \\ ${ }^{1}$ Prodi Pendidikan Kesejahteraan Keluarga, Universitas Pendidikan Indonesia JI. Dr. Setiabudhi No. \\ 229 Bandung 40154 Jawa Barat-Indonesia, Telp. 022-2013163 Fax. 022-2013651, Email: prodi- \\ pkk@upi.edu
}

\begin{abstract}
Abstrak
Penelitian ini dilatarbelakangi belum adanya program perawatan kebersihan diri (personal hygiene) berbasis life skill untuk anak prasekolah di Panti Sosial Asuhan Anak (PSAA). Penyuluhan perawatan kebersihan diri (personal hygiene) untuk anak prasekolah ini bertujuan untuk membantu penyuluh dalam memberikan pembekalan mengenai perawatan kebersihan diri (personal hygiene) untuk anak prasekolah (usia 3-6 tahun). Tujuan dari penelitian ini adalah untuk menghasilkan program penyuluhan perawatan kebersihan diri (personal hygiene) berbasis life skill untuk anak prasekolah di Panti Sosial Asuhan Anak dalam bentuk Buku Panduan. Penelitian ini menggunakan metode Research and Development (R\&D) dengan model penelitian PPE yang meliputi Planning, Production, dan Evaluation. Hasil expert judgment mengenai program penyuluhan perawatan kebersihan diri (personal hygiene) berbasis life skill untuk anakprasekolah berada pada kriteria sangat layak terdiri atas: identitas program, tujuan, materi, metode, skenario kegiatan, dan evaluasi program. Rekomendasi untuk pengelola PSAA dan peneliti selanjutnya, hendaknya program penyuluhan perawatan kebersihan diri (personal hygiene) untuk anak prasekolah yang telah memiliki kelayakandapat diimplementasikan serta dijadikan panduan pelaksanaan program perawatan kebersihan diri (personal hygiene) berbasis life skill untuk anak prasekolah di Panti Sosial Asuhan Anak (PSAA).
\end{abstract}

Kata Kunci: Program penyuluhan, kebersihan diri, life skill, anak prasekolah

\section{COUNSELING PROGRAM OF PERSONAL HYGIENE BASED ON LIFE SKILL FOR PRESCHOOL CHILDREN IN ORPHANAGE}

\begin{abstract}
This main reason of this reseaserch is the absence of treatment programs particularlly personal hygiene and cleanliness based on the life skill for preschooler in social childcare institutions or orphanage. The elucidation care of personal hygiene and cleanliness is aims to help extension to the provision concerning the treatment personal hygiene and cleanliness for them. The purpose of this research is to produce a counseling program of personal hygiene and cleanliness care based on the life skill for children in social institution of preschooler in the form of a guidebook. This study use of research and development with the research PPE approach covering planning, production, and evaluation. The
\end{abstract}


explicitness directness on the socialization program to care cleanliness (personal hygiene) based on the life skill for preschooler is in very reasonable criteria, such as program consists of identity, the purpose, matter, method, scenario, activities, and evaluation. Recommendations for the next researchers and care instution management is to implement and use the book of cleanliness and personal hygiene program for preschooler with feasibility be able to be as a guide to theses treatment programs based on the life skill for them in social institutions.

Keywords: Counseling program, Personal hygiene, life skills, pre-schooler

\section{PENDAHULUAN}

Pendidikan yang diselenggarakan di Negara Kesatuan Republik Indonesia (NKRI) terbagi dalam tiga jalur, yaitu pendidikan formal, pendidikan nonformal, dan pendidikan informal sebagaimana yang diatur dalam Undang-Undang Nomor 20 Tahun 2003, Pasal 26 ayat 1 dijelaskan bahwa pendidikan nonformal diselenggarakan bagi warga masyarakat yang memerlukan layanan pendidikan yang berfungsi sebagai pengganti, penambah dan atau pelengkap pendidikan formal dalam rangka mendukung pendidikan sepanjang hayat atau longlife education. Di Indonesia upaya untuk memperkuat ketahanan keluarga masih dilakukan secara non formal dan informal, belum terdapat program yang secara sistematik dan periodik dilakukan untuk memperkuat ketahanan keluarga (Rohaeni, Ningsih, dan Jubaedah, 2018).

Mabrorroh, Auliya (2015) menyebutkan bahwa salah satu lembaga yang menjalani pendidikan nonformal adalah Panti Asuhan. Panti Sosial Asuhan Anak (PSAA) adalah salah satu lembaga yang melindungi hak-hak anak dan menjadi keluarga dalam memberikan layanan secara fisik maupun mental sosial. Masyarakat dan pemerintah berhak membantu memberikan pemeliharaan dan perawatan terhadap anak mencakup beberapa aspek kehidupan, salah satunya adalah aspek pendidikan.

Khoirunnisa, Ishartono, dan Resnawaty (2015, hlm. 72-73) mengungkapkan bahwa keutamaan dalam pelayanan dan pendidikan yang diberikan oleh pengasuh dan pengurus di Panti Sosial Asuhan Anak (PSAA) adalah berorientasi pada setiap kebutuhan tumbuh kembang anak. Pengasuh dituntut untuk dapat menjadi orang tua sekaligus guru yang mampu mengawasi tumbuh kembang dan melatih kecakapan hidup (life skill) anak-anak di PSAA. Life skill adalah modal dasar individu yang dapat bermanfaat sepanjang hayat karena dapat mendorong kemandirian. Life skill terdiri dari generic life skill (kecakapan hidup umum) dan specific life skill (kecakapan hidup khusus). Generic life skill meliputi kecakapan personal, berpikir rasional dan sosial sedangkan specific life skill meliputi kecakapan akademik dan kecakapan vokasional.

Pengasuh juga diharapkan dapat menyelesaikan permasalahan yang dihadapi oleh anak asuh di PSAA, salah satunya adalah permasalahan yang berasal dari pribadi masing-masing anak karena anak yang berada di PSAA berasal dari keluarga berbeda-beda. Tidak semua anak yang berada di PSAA mengerti tugas atau kewajiban yang seharusnya sudah bisa dirinya lakukan. Permasalahan lainnya dapat disebabkan karena anak-anak di PSAA tidak mendapatkan perhatian dan kasih sayang sebagaimana anak-anak di luar PSAA yang masih memiliki orang tua lengkap. Tidak hanya karena mereka yatim piatu dan sudah tidak memiliki keluarga yang dapat mengurus mereka saja, tetapi juga karena perbandingan jumlah anak dengan pengasuh di PSAA yang kurang seimbang (Khoirunnisa, Ishartono, dan Resnawaty, 2015, hlm. 72-73).

Berdasarkan hasil wawancara yang peneliti lakukan di Panti Sosial Asuhan Anak Al Fien Bandung dan Panti Sosial Asuhan Anak Al Kautsar pada bulan Juni tahun 2019, meskipun para pengasuh sudah menganggap, menyayangi dan memperhatikan anak selayaknya anak sendiri, tetapi perhatian dan kasih sayang dari pengasuh harus terbagi kepada banyaknya jumlah anak di PSAA karena satu pengasuh diberikan tanggung jawab 5-10 orang anak. Sesuai dengan penelitian Khoirunnisa, Ishartono, dan Resnawaty $(2015$, hlm. 69) yang menyimpulkanbahwa anak di panti seringkali mengalami kekurangan perhatian dan kasih sayang dikarenakan jumlah pengasuh di panti 
yang sedikit dan tidak sebanding dengan banyaknya anak sehingga anak yang besar di panti seringkali tertinggal dibanding anak seusia mereka yang mengalami pengasuhan dalam keluarga.

Masalah tersebut berpengaruh pada salah satu kecakapan atau keterampilan hidup yang dapat bermanfaat sepanjang hayat (longlife skills) bagi tumbuh kembang anak yaitu perawatan kebersihan diri (personal hygiene). Personal hygiene anak menurut Aulia, Muhlisin, dan Kartinah (2014, hlm. 15) adalah aspek penting terkait kebersihan diri individu yang mencakup beberapaaspek seperti, perawatan kulit kepala, rambut, mata, hidung, telinga, kuku tangan, kaki, dan perawatan tubuh secara keseluruhan. Personal hygiene harus diajarkan kepada anak sedari anak masih berusia prasekolah karena awal masa kanak-kanak merupakan masa yang tepat untuk belajar berbagai hal guna meningkatkan berbagai keterampilan karena pada masa prasekolah anak sedang senang mengulangulang, berani dan senang mencoba sesuatu yang baru yang secara tidak sadar sesuatu yang baru tersebut akan menjadi sebuah kebiasaan apabila terus diulang (Alisuf dalam Arief dkk., 2010, hlm. 2).

Rendahnya daya tahan tubuh anak prasekolah juga dijelaskan Alimul (dalam Putri, Maemunah, dan Wahidyanti, 2016, hlm. 56) dapat memungkinkan mengundang banyak penyakit jika personal hygine anak tidak diperhatikan. Menurut Wong (dalam Putri, Maemunah, dan Wahidyanti, 2016, hlm. 55), faktor gizi, penyakit, kesehatan gigi, masalah tidur, serta cara orang tua atau pengasuh dalam merawat anak juga mempengaruhi pertumbuhan dan perkembangan yang terjadi saat anak masih berusia prasekolah. Pendidikan kesehatan untuk anak pra sekolah di PSAA dinilai penting diberikan dan dapat berupa program penyuluhan perawatan kebersihan diri. Anak prasekolah di PSAA yang menjadi sasaran adalah anak prasekolah yang berusia 3-6 tahun(Dewi, Oktiawati, dan Saputri, 2015).

Nototoatmodjo (dalam Arief dkk, 2010, hlm. 1) menjelaskan bahwa anak prasekolah lebih mudah dibimbing, diarahkan dan ditanamkan kebiasaan yang baik, termasuk kebiasaan hidup sehat seperti personal hygiene. Personal hygiene merupakan salah satu dari 12 kelompok long life skills yang harus dikuasai anak menurut identifikasi Field, C. M (dalam Suri, 2010, hlm. 1), yaitu healthy lifestyle skills (kecakapan atau keterampilan gaya hidup sehat). Life skill anak pada dasarnya adalah longlife skill yang dapat bermanfaat sepanjang hayat, penting dikuasai dan mulai diterapkan pada kehidupan anak selagi anak masih berusia prasekolah terutama personal hygiene karena berkaitan dengan kebutuhan, kebersihan, kesehatan, dan kenyamanan diri anak sepanjang hidupnya yang diajarkan melalui pendidikan kesehatan secara non formal seperti penyuluhan.

Penyampaian materi perawatan kebersihan diri di PSAA AI Fien dan Al Kautsar juga kurang menarik karena hanya menggunakan cerita dongeng yang dikarang oleh pengasuh saja. Padahal, penyampaian materi dalam program penyuluhan untuk anak harus beragam dan dapat menarik perhatian anak sehingga anak lebih mudah mengingat materi tersebut. Penyampaian materi bisa disampaikan dengan media pembelajaran berupa gambar sebagai alat bantu pandang, suara sebagai alat bantu dengar, serta audio visual atau video edukasi sebagai alat bantu pandang dan dengar yang dapat mendukung salah satu program pemerintah, yaitu Perilaku Hidup Bersih dan Sehat (Arief dkk, 2010, hlm. 1).

Departemen Kesehatan RI dalam (Zakiudin dan Shaluhiyah, 2016, hIm. 65), Perilaku Hidup Bersih dan Sehat atau PHBS adalah semua perilaku sehat yang dilakukan atas dasar kesadaran untuk menolong diri sendiri dan anggota keluarga di bidang kesehatan serta dapat berperan aktif dalam melaksanakan kegiatan-kegiatan kesehatan masyarakat. Namun, PHBS tidak difokuskan untuk anak prasekolah dan berdasarkan wawancara kepada pengelola PSAA Al Fien Bandung dan PSAA AI Kautsar Lembang, peneliti menyimpulkan belum ada program perawatan kebersihan diri (personal hygine) berbasis life skill yang difokuskan untuk anak prasekolah. Perawatan kebersihan diri anak prasekolah di kedua PSAA tersebut juga hanya merupakan suatu kebiasaan yang wajib dilakukan tetapi bukan pengasuh yang mengawasi anak tersebut secara langsung, melainkan anak yang berumur lebih tua di PSAA tersebut.

Berdasarkan masalah tersebut, penelitian ini bertujuan membuat program penyuluhan perawatan kebersihan diri atau personal hygiene berbasis life skill untuk anak prasekolah di Panti Sosial Asuhan Anak (PSAA) dalam bentuk Buku Panduan. Dalam pelaksanaan program penyuluhan tersebut, tidak hanya anak prasekolah di PSAA yang ikut serta, tetapi para pengasuh sebagai orang tua juga 
dilibatkan dalam pendampingan cara membiasakan perawatan kebersihan diri anak prasekolah karena pengasuh akan menjadi pelaksana.

\section{METODOLOGI PENELITIAN}

Metode penelitian yang digunakan dalam penelitian ini adalah research and development (penelitian dan pengembangan) atau biasa disebut dengan istilah $R \& D$. Model yang digunakan dari metode researchanddevelopment dalam penelitian menggunakan model PPE (planning, production, evaluation). Tahap-tahap penelitian yang akan dilakukan dalam penelitian ini adalah Planning, Production, Evaluation (PPE) yang diadaptasi dari Richey dan Klein (2009), sebagai berikut:

1. Planning (Perencanaan)

Perencanaan dalam penelitian ini adalah identifikasi masalah, analisis kebutuhan, dan perancangan komponen program penyuluhan perawatan kebersihan diri (personal hygiene) berbasis life skill untuk anak prasekolah di Panti Sosial Asuhan Anak.

2. Production (Pembuatan)

Pembuatan program penyuluhan perawatan kebersihan diri (personal hygiene) berbasis life skill untuk anak prasekolah di Panti Sosial Asuhan Anak. Komponen program penyuluhan terdiri atas komponen program, yaitu : identitas progam, tujuan, materi, metodologi, waktu pelaksanaan, dan skenario kegiatan program penyuluhan.

3. Evaluation (Evaluasi)

Evaluasi program penyuluhan perawatan kebersihan diri (personal hygiene) untuk anak prasekolah di Panti Sosial Asuhan Anak melalui expert judgment.

Partisipan sebagai sumber data penelitian terdiri dari: 2 orang ahli pendidikan nonformal, praktisi penyuluhan kesehatan anak, pengasuh PSAA Al Fiendan Al Kautsar.

Teknik pengumpulan data menggunakan format validasi berisi criteria kelayakan berkaitan dengan komponen da $\mathrm{n}$ isi program penyuluhan perawatan kebersihan diri (personal hygiene) berbasis life skill untuk anak prasekolah.

Teknik pengolahan data disesuaikan dengan karakteriristik data yang diperoleh yaitu untuk data kualitatif dianalisis secara kualitatif dan untuk data kuantitatif dianalisis secara kuantitatif.

\section{HASIL DAN PEMBAHASAN}

Dari hasil penelitian melalui tahapan PPE telah menghasilkan program penyuluhan perawatan kebersihan diri (personal hygiene) berbasis life skill untuk anak prasekolah di Panti Sosial Asuhan Anak (PSAA) dalam bentuk buku panduan yang dapat digunakan oleh pendamping anak. Buku Panduan yang dihasilkan tersebut sudah melalui expert judgement oleh ahli pendidikan nonformal, praktisi penyuluhan kesehatan dan pengasuh di PSAA.

Buku panduan berisi tentang tahapan program penyuluhan perawatan kebersihan diri (personal hygiene) berbasis life skill untuk anak prasekolah di Panti Sosial Asuhan Anak (PSAA) yang terdiri atas:identitas program (nama program, lokasi, sasaran, waktu pelaksanaan, jumlah pertemuan), tujuan program (tujuan umum dan tujuan khusus), metodologi program (metode, pendekatan, media, dan sumber belajar), materi penyuluhan, skenario kegiatan, dan evaluasi program. Hasil validasi menyatakan bahwa program yang sudah dibut secara keseluruhan dinyatakan sangat layak untuk diimplementasikan dengan persentase $94,4 \%$.

Tujuan program penyuluhan perawatan kebersihan diri (personal hygiene) dirumuskan pada pendapat Kartika (2011) yang menyatakan bahwa tujuan merupakan arahan atau acuan terjadinya pelaksanaan program. Tujuan merupakan target atau maksud yang hendak dituju melalui beberapa 
langkah. Menurut Hamid (2013), Tujuan program dibagi menjadi dua, yaitu tujuan umum dan tujuan khusus. Tujuan umum menunjukkan output dari program jangka panjang, sedangkan tujuan khusus menunjukkan output jangka pendek. Selain berdasarkan pendapat tersebut, peneliti juga membuat tujuan program berdasarkan analisis kebutuhan dan (expert judgment) dengan hasil validasi“sangat layak".

Materi program dikembangkan mengacu pada pendapat Basri (2015) yang menyatakan materi yang dirumuskan harus sesuai kebutuhan anak yang dapat disampaikan dengan bermain sambil belajar. Selain berdasarkan pendapat tersebut, peneliti juga menentukan materi program berdasarkan analisis kebutuhan dan expert judgment dengan hasil validasi sangat layak". Materi yang dikembangkan mencakup: pengertian perawatan kebersihan diri (personal hygiene), tujuan dan manfaat dari menjaga perawatan kebersihan diri (personal hygiene), ketentuan atau etika perawatan kebersihan diri, perawatan kebersihan mata, telinga, hidung, mulut atau gigi, kuku, rambut, dan perawatan kebersihan genital atau alat kelamin.

Metode program yang peneliti rumuskan selain berdasarkan analisis kebutuhan dan validasi (expert judgment), juga metodologi program terdiri dari metode, pendekatan, media, dan sumber belajar. Pemilihan metode disesuaikan dengan situasi peserta, serta karakteristik dari setiap materi dan tujuan yang hendak dicapai (Nugroho, 2014). Metode yang peneliti pilih berdasarkan pendapat Khusna, D. (2013) yang menyatakan metode pada tiap program untuk anak adalah sarana mencapai tujuan agar anak pra sekolah memperoleh pengalaman belajar yang bermanfaat dan menyenangkan. Maka, metode program penyuluhan perawatan kebersihan diri (personal hygiene) berbasis life skill untuk anak prasekolah di Panti Sosial Asuhan Anak yang telah peneliti pilih untuk program ini adalah ceramah, bercerita, bermain, bernyanyi, modelling, dan learning by doing dengan pendekatan langsung dan kelompok, serta media pendukung berupa buku atau kartu bergambar dan video.

Skenario kegiatan berupa urutan langkah-langkah dari awal kegiatan sampai akhir kegiatan. Rancangan skenario kegiatan terdiri dari kegiatan pendahuluan, kegiatan inti, dan kegiatan penutup (Nugroho, 2014). Kegiatan pendahuluan merupakan awal dalam suatu pertemuan yang bertujuan untuk membangkitkan motivasi dan perhatian peserta untuk berpartisipasi aktif dalam kegiatan. Ini kegiatan merupakan kegiatan untuk mencapai tujuan, sedangkan kegiatan penutup merupakan kegiatan yang akhir dalam bentuk rangkuman atau kesimpulan.

Evaluasi program berupa rubrik penilaian (keaktifan peserta), daftar pertanyaan lisan dan lembar penilaian praktik peserta berada pada kriteria sangat layak. Sudjana (dalam Ananda dan Rafida, 2017, hlm. 3) memaknai evaluasi sebagai kegiatan mengumpulkan,mengolah dan menyajikan data untuk masukan dalam pengambilan keputusanmengenai program yang sedang dan/ atau telah dilaksanakan.

\section{KESIMPULAN}

1. Program penyuluhan perawatan kebersihan diri (personal hygiene) berbasis life skill untuk anak prasekolah di Panti Sosial Asuhan Anak (PSAA) yang dihasilkan dalam bentuk buku panduan sudah sangat layak untuk diimplementasikan.

2. BukuPanduan yang dihasilkan berisi program penyuluhan perawatan kebersihan diri (personal hygiene) berbasis life skill untuk anak prasekolah di Panti Sosial Asuhan Anak (PSAA) terdiri atas kompenen identitas program, tujuan program, materi program, metode program, skenario kegiatan program, dan evaluasi program.

3. Buku panduan yang berisi program penyuluhan dapat digunakan oleh pendamping anak atau pengasuh dalam melaksanakan penyuluhan perawatan kebersihan diri (personal hygiene) berbasis life skill untuk anak prasekolah di Panti Sosial Asuhan Anak (PSAA).

\section{DAFTAR PUSTAKA}


Ananda dan Rafida. (2017). Pengantar Evaluasi Program Pendidikan. Medan: Perdana Mulya Sarana.

Arief dkk. (2010). Upaya Meningkatkan Kebersihan Perorangan Melalui Buku Cerita Kontemporer. Jurnal Ners 5 (1), April 2010: hlm. 1-9.

Aulia, Muhlisin, Kartinah. (2014). Pengaruh Pendidikan Kesehatan Tentang Personal Hygiene terhadap Pengetahuan dan Sikap Siswa SDN Rembes 1 Dusun Watugimbal Kecamatan Beringin Kabupaten Semarang. Naskah Publikasi. Jurusan Keperawatan Fakultas IImu Kesehatan Universitas Muhammadiyah Surakarta. hlm. 2.

Basri. (2015). Peran Metode untuk Mencapai Tujuan Pembelajaran. 11(2), hlm. 113-131.

Dewi, R.C., Oktiawati, A., dan Saputri, L.D., (2015). Teori \& Konsep Tumbuh Kembang Bayi, Toddler, Anak dan Remaja. Yogyakarta: Nuha Medika.

Hamid, Abdul. (2013). Manajemen Program (Amil Development Program) pada Lembaga IMZ. Skripsi Universitas Islam Negeri Syarif Hidayatullah Jakarta.

Kartika. (2011). Modul Belajar dan Pembelajaran. Bandung: Alfabeta.

Khoirunnisa, S., Ishartono, I, dan Resnawaty, R. (2015). Pemenuhan Kebutuhan Pendidikan Anak Asuh di Panti Sosial Asuhan Anak. Jurnal UNPAD Prosiding PKM., 2(1) hlm. 69-73.

Khusna, D. (2013). Analisis Kebutuhan Pembelajaran Dalam Perancangan Pembelajaran. Malang: Universitas Islam Negeri Maulana Ibrahim.

Mabrorroh, Auliya. (2015). Pembinaan Kreativitas Anak Yatim Piatu Melalui Program Kesenian Gamelan: (Studi Deskriptif di Panti Sosial Asuh Anak Tambatan Hati Kota Bandung). Bandung: Perpustakaan Universitas Pendidikan Indonesia.

Nugroho, N. B. (2014). Pengembangan RPP Dan LKS Berbasis Problem Based Learning. Skripsi.

Putri, Maemunah, dan Wahidyanti. (2016). Pemeriksaan Pertumbuhan dan Personal Hygiene Anak Pra Sekolah di RA Pesantren Al Madaniyah. Jurnal Akses Pengabdian Indonesia 1(5), hlm.55-64

Richey dan Klein.(2009). Penelitian Dan Pengembangan. Bandung: Alfabeta.

Rohaeni, N., Ningsih, M.P., dan Jubaedah, Y. (2018). Model Pendidikan Kehidupan Keluarga Berbasis Life Skill Dalam Meningkatkan Ketahanan Keluarga. 4(2) hlm. 63-68.

Suri, Dharlinda. (2010). Pengembangan Kecakapan Hidup Bagi Anak Usia Dini di Kelompok Rasyidul Jannah (Studi Kualitatif di Desa Bakung llir Kabupaten Tulang Bawang Provinsi Lampung Tahun 2009-2010).

Undang-Undang Nomor 20. (2003). Pasal 26 ayat 1. UUD NKRI

Zakiudin dan Shaluhiyah. (2016). Perilaku Kebersihan Diri (Personal Hygiene) Santri di Pondok Pesantren Wilayah Kabupaten Brebes akan Terwujud Jika Didukung dengan Ketersediaan Sarana Prasarana. Jurnal Promosi Kesehatan Indonesia 11(2). 